\title{
Homeowners' Decisions Towards Energy Renovations - Critical Stages and Sources of Information
}

\author{
Shima Ebrahimigharehbaghi ${ }^{1}$, Queena K. Qian ${ }^{1}$, Frits M. Meijer ${ }^{1}$, Henk J. Visscher ${ }^{1}$ \\ ${ }^{1}$ Delft University of Technology, Faculty of Architecture and the Built Environment (OTB)
}

\begin{abstract}
The European Commission aims to decrease GHG emissions to 80\% below 1990 levels by 2050 (EU, 2017). The housing stock has a considerable share that equals to $40 \%$ of energy consumption and $36 \%$ of emissions in the EU. The current research aims to evaluate the homeowners' energy renovation decisions on the exterior, interior, and insulation/installation of their house. The householders' renovation decisions are analyzed with regards to (1) which stages to help/support and (2) what information is essential in the renovation process. Considering the extent of difficulty for private homeowners' in accessing information and complexity in conducting the renovation, transaction cost (TC) theory is applied in understanding the decisions. The data has been collected through a survey among 3,776 of the Dutch homeowners in 2012. Then, statistical and logistic regression analysis has been conducted to analyze the renovation decisions for two groups of homeowners: renovators and potential renovators. According to the results and the outcomes of this study: (1) For the renovators: (a) the main identified stages in getting help are in carrying out the renovation, determining the costs, and looking for the reliable professional/ contractor, (b) the main identified sources of information are at the maintenance/ installation companies, family/ friends, and via internet; (2) For the potential renovators: (a) the main identified help stages are in determining the costs, looking for a reliable professional and carrying out the renovation/ improvement, (b) the main identified sources of information are via the internet, by a maintenance/ installation companies, and family/ friends. The main difference among the renovators is for insulation/ installation. The most significant stage in getting help for insulation/installation is to find out the most efficient solutions. Similar results have been found for the potential renovators; the only difference was in the order of the influencing factors.
\end{abstract}

\section{Introduction}

The housing stock has a considerable share in energy consumption ${ }^{1}$. In the Netherlands, the owner-occupied sector takes a significant share of $69.4 \%$ of the building stock. In Europe, the energy label system is used to measure the performance of the building stock. In the Netherlands, the energy label D is the average for the Dutch owner-occupied sector ${ }^{2-4}$. Considering a high share of housing and relatively low average energy label, the owner-occupied sector in the Netherlands has a high potential in reducing the energy consumption in the housing stock. It is, therefore, chosen as the focus of our paper.

The aim of renovations by the households is to improve the conditions of the house or to make it more comfortable ${ }^{5,6}$. However, there are barriers in the renovation process which affect the willingness in investing and renovating by the households ${ }^{7}$. For instance, homeowners cannot easily finance the energy renovation investment, and the process is very complicated. In the Netherlands, the private banking system supports the householders in the renovation by providing mortgages more than the house values. However, the complexities in getting the loans/ subsidies might hinder the homeowners from applying. Additionally, there are uncertainties in the expected benefits of energy efficiency renovations compared to the mortgage costs ${ }^{8}$.

In a renovation process, different stages have hidden costs that are not taken into account but affect their faith in renovation decision. For instance, in an early stage, householders have to spend time and resources in evaluating the costs and benefits of the renovation. In this paper, a specific type of barriers- transaction costs, is investigated. In any transaction with an external party, some hidden costs exist that the institutional economist called it the 'Transaction Cost (TC)'. The elements that cause the TC are asset specificity, uncertainty, and frequencies. By increasing the asset specificity and uncertainty, the TC escalates ${ }^{7,9-11}$.

In this paper, the aim is to address the homeowners' transaction cost barriers at different stages of a renovation process. Logistic regression is conducted to examine the importance of TCs barriers quantitatively, between two target groups of householders: the renovators and potential renovators. By energy renovations, we refer to any improvement or significant changes in three different parts of the house; exterior, interior, and insulation and installation.

Section 2 reviews the literature on transaction costs. Section 3 describes the methodology and database of the survey. Sections 4 and 5 present subsequently the results of the analyses, and conclusions.

\section{Theoretical Background}

The literature on the TCs are reviewed from homeowners' and other stakeholders' perspectives, then the TCs typology and measurement indicators are aligned along the renovation process. Theoretical framework including the renovation stages and related TCs are developed for empirical analysis.

\footnotetext{
* Corresponding author: S.Ebrahimigharehbaghi@tudelft.nl
} 


\subsection{State-of-the-art}

\subsubsection{Definition}

TC means any unavoidable indirect cost in a transaction that negatively affects the consumers' decision ${ }^{12}$. It is a sub-category of 'hidden costs' that have not been adequately considered in the cost analysis and consisting of a search for information, negotiating and monitoring costs. ${ }^{13}$ Three main elements cause the transaction costs: (a) asset specificity: TC can be created whether an asset is allocated for a specific purpose. In case of renovation, the asset specificity can be explained for both human and physical assets. The example of a physical asset is an investment in specific technologies/measurements, and the human asset is the essential skills/knowledge for a renovation, (b) uncertainty: any opportunistic behavior/ asymmetric information affects the confidence/ trust/ certainty in making a decision. In renovation decision, two main types of uncertainties exist uncertainty in the expected benefits and opportunistic behavior of other actors, and (c) frequency: the element is related to the uncertainty. By experiencing the renovation and doing more renovation, uncertainties will reduce ${ }^{14}$.

\subsubsection{Initial research on TCs}

New institutional economics have applied TC theories in explaining the behavior of market agents mainly through imperfect and asymmetric information. The main and starting point in the TC studies focus on the organization and enterprise level of analysis ${ }^{15,16}$. The studies focus on different aspects, (a) in the planning phases, such as searching for information ${ }^{17}$, (b) in the executing phase, controlling, and enforcing ${ }^{16}$, (c) and overall activities ${ }^{18,19}$. The current study follows the last category of the literature and considers the TCs of the overall activities in the renovation process.

\subsubsection{Householders' perspective}

Few studies have investigated the TC from householders' perspectives in the renovation processes ${ }^{20}$. Some literature has analyzed the homeowners' TC, not for the renovation decision, but other activities, such as the impact of transaction cost on more stay in a particular house ${ }^{21}$. The second group has partly considered the TCs along with other influencing factors ${ }^{7}$, and not much research on the householders' TC for the renovation process. Among them, some researchers aim to quantify the TC. For instance, Bjorkqvist and Wene (1993) ${ }^{20}$ estimated the TC in changing the heating system equal to 18 hours for Swedish single family dwellings (13-28\% of the predicted investment cost). The authors have defined the TC as a time spent in each decision stage. To quantify the TC have aroused some critics due to unclear time allocation for a specific activity.

\footnotetext{
${ }^{1}$ Bounded rationality has two blades; cognitive limitation of an agent and environment structure around the agent ${ }^{34}$.
}

\subsubsection{Insights from other actors' perspectives}

Mundaca et al. $(2013)^{10}$ have reviewed TCs comprehensively from investors/project developers' perspectives. The assumption is that agents have bounded rationality $^{1}$ and do not have access to complete information. In their article, the authors developed a taxonomy for TCs consisting of five types of costs: search for information costs, negotiation costs, approval and certification costs, monitoring and verification costs, and trading costs. Besides, the authors explained a list of factors in the implementation and operation of low-carbon technologies that are influencing the nature and scale of TCs. Endogenous factors, such as the size and complexity of the project, the high number of intermediaries, and fewer experiences in doing a project might increase the TC. Finally, an interesting finding of their research is that the sources and estimates of TCs are specific to the cases and circumstances.

Qian et al. (2014) ${ }^{22}$ developed a TC framework from the real estate developers' and householders' perspective. The aim was to study the reluctance of the market to invest in energy efficiency measures. The authors concluded that TCs are the main factors hindering building energy efficiency market penetration. Another research done by Qian et al. (2015) ${ }^{23}$, assumed the individual stakeholders steadfastly guard their interests in any investment decisions. The authors investigated the extra TCs affecting the willingness of the stakeholders to take part in green investment. The findings manifested that the choice between developers and end-users over investing in green building is a complex game problem, where TC could be conceptualized and showed their essential role. By minimizing the TCs incurred in the complex decision, it will not only beneficial to the stakeholders involved but also bring net regenerative outcomes to society.

\subsubsection{Measurement indicators of TC}

In a renovation and from householders' perspective, TC can be categorized into the following three aspects:

(a) Time and effort in finding information/ knowledge/ experts/ financial support, etc. The householders are usually not educated with knowledge of technology, construction measures or financial schemes. Therefore, there is a need to find a way to the trustworthy source of information themselves, or access to the experts $^{24-27}$;

(b) Complexity in a renovation process, such as the cognitive burden of making complex and irreversible decisions, or complexity in implementing the renovation ${ }^{7}$; 
(c) Disruption in the ordinary life and likely hassle factor during the renovation; and

(d) Time and effort in finding a reliable information/expert.

TCs is higher in the presence of imperfect and asymmetric information since the householders might pay higher prices to access reliable information/ professional ${ }^{28}$. Finally, the barriers related to the TC might lead to a nonoptimal investment of a renovation process.

\subsection{Conceptual framework}

A renovation consists of different stages including considering phase (understanding the needs, information searching and pre-evaluating), planning, finalizing the decision, executing, and experiencing (post-evaluating) ${ }^{29}$. In considering phase, the critical influencing factors are socioeconomic factors, such as age, education, and income. In the planning phase, awareness of the benefits can persuade homeowners to renovate. Consequently, he householders need to investigate different aspects, such as different stages that they encounter for a specific type of renovation, or necessary permits for a renovation that they might need to acquire ${ }^{11,27,30}$. Additionally, before making a decision, it is essential to have information about the energy-saving measures. After decision-making and implementing the renovations, the experiences are circulated through social networks of the householders. This circulation of information also influences the future renovation for other householders ${ }^{31}$. Table 1 explains the $\mathrm{TC}$ in different stages of renovation processes.

Table 1. Transaction costs in different stages of a renovation based on the literature review

\begin{tabular}{|c|c|c|}
\hline Stage & a) Considering & b) Planning \\
\hline $\mathrm{TC}$ & $\begin{array}{l}\text { - Time and effort to } \\
\text { determine the costs } \\
\text { and benefits of } \\
\text { renovation } \\
\text { - Time and effort to } \\
\text { determine the } \\
\text { available ESMs } \\
\text { - Time and effort to } \\
\text { determine the } \\
\text { appropriate ESMs }\end{array}$ & $\begin{array}{l}\text { - Time and effort to } \\
\text { get the essential permit } \\
\text { for renovation } \\
\text { - Time and effort to } \\
\text { find the stages in } \\
\text { renovation } \\
\text { - Time and effort in } \\
\text { finding people who } \\
\text { share the experiences } \\
\text { - Time and effort for } \\
\text { planning }\end{array}$ \\
\hline $\begin{array}{l}\text { TC } \\
\text { Element }\end{array}$ & $\begin{array}{l}\text { - Asset specificity } \\
\text { - Uncertainty }\end{array}$ & $\begin{array}{l}\text { - Asset specificity in } \\
\text { knowledge and skills } \\
\text { - Uncertainty in } \\
\text { planning }\end{array}$ \\
\hline
\end{tabular}

\begin{tabular}{|l|l|l|}
\hline Stage & \multicolumn{1}{|c|}{ c) Decision } & \multicolumn{1}{c|}{ d) Executing } \\
\hline TC & $\begin{array}{l}\text { • Time and effort to } \\
\text { find reliable } \\
\text { professional and } \\
\text { experts } \\
\text { • Time and effort to } \\
\text { find subsidies/ } \\
\text { benefits }\end{array}$ & $\begin{array}{l}\text { - Mess and nuisance } \\
\text { during the renovation } \\
\text { • Uncertainty in doing } \\
\text { by myself/contractors }\end{array}$ \\
\hline
\end{tabular}

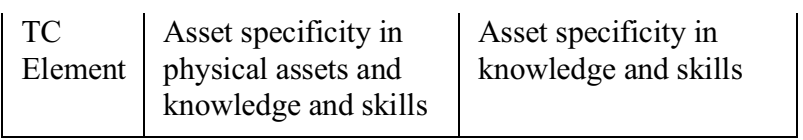

\begin{tabular}{|l|l|}
\hline Stage & \multicolumn{1}{|c|}{ e) Experiencing } \\
\hline TC & $\begin{array}{l}\text { Time and effort in } \\
\text { finding the next steps in } \\
\text { the renovation }\end{array}$ \\
\hline TC Element & $\begin{array}{l}\text { Asset specificity in } \\
\text { knowledge and skills }\end{array}$ \\
\hline
\end{tabular}

\section{Methodology}

\subsection{Survey and database}

A survey has been conducted among 3,776 homeowners in the Netherlands. The questionnaire contains three sections: a) households features and b) buildings features, c) the renovation in the exterior, interior, and insulation and installation. The homeowners answered if they have done/ planned a renovation in the last/next two years.

\subsection{Method of Analysis}

The importance of getting help in different stages of renovation decisions and the sources of information are investigated using the logistic regression. In the analysis, the dependent variable is the renovation decision and binary. There are some assumptions in conducting logistic regressions, including binary dependent variable, not having multicollinearity between independent variables and large sample size. We have tested all these assumptions, and the assumptions have been verified. The Variance Inflation Factors (VIF) are conducted to test the multicollinearity among independent variables. The VIF $=2.5$ is the initial point of concern and VIF greater than 10 shows multicollinearity ${ }^{32}$.

$$
\begin{gathered}
\log \frac{P(\text { renovation })}{1-P(\text { renovation })}= \\
X_{\text {Socio-demographic variables }}+X_{\text {Drivers }}+X_{\text {Barriers }}
\end{gathered}
$$

Where $\mathrm{P}$ is the probability of the events, and $\mathrm{X}$ represents independent variables. After estimation, the model is validated by the Omnibus tests of model coefficients and the Hosmer and Lemeshow test. The Omnibus test demonstrates whether the model predicts the outcome with the explanatory variables better than without ${ }^{33}$. The Omnibus tests are statistically significant, and the models are validated. The Hosmer and Lemeshow test indicate the goodness of fit. This test should not be significant to represent a good model which were not significant in our regressions. 


\section{Results}

In this part, the results of the regression analysis are presented. The important stages and sources of information of renvators and potential renovators are explained in the tables of each subsection. Table 2 shows the list of TCs factors in the regression analysis. The socio-demographic factors are also included in the regression analysis.

Table 2. Critical stages and sources of information (independent variables)

\begin{tabular}{|l|l|}
\hline Stages & $\begin{array}{l}\text { Sources of } \\
\text { information }\end{array}$ \\
\hline $\begin{array}{l}\text { (1) Determining if the house } \\
\text { maintenance is good enough, }\end{array}$ & (1) Maintenance/ \\
installation \\
(2) Planning the work, & company \\
$\begin{array}{l}\text { (3) Determining the costs, } \\
\text { (4) Finding funding/ financing, }\end{array}$ & (3) Internet \\
$\begin{array}{l}\text { (5) Finding a good professional/ } \\
\text { contractor, }\end{array}$ & (4) Construction \\
$\begin{array}{l}\text { (6) Carrying out the renovation/ } \\
\text { improvement, making a more energy- } \\
\text { efficient house, and Performing the } \\
\text { work (the householders). }\end{array}$ & (5) Municipality \\
\hline
\end{tabular}

\subsection{Critical stages and sources of information in the exterior part of a building}

Based on the analysis, the critical stages are similar for the renovators and potential renovators. The regression analyses are presented in For the potential renovators, the significant stages in help acquisition of potential renovators are whether they are planning to do the work and finding a reliable professional/ contractor. The respondents that have indicated asking information from family and friends are more likely to do a renovation (Table 4).

Table 4. Logistic regression on exterior renovation decision in the next 2 years (potential renovators)

\begin{tabular}{lrrrl}
\hline & \multicolumn{1}{l}{ B } & \multicolumn{1}{l}{ S.E. } & \multicolumn{1}{l}{ Wald } & \multicolumn{1}{l}{ Sig. } \\
\hline Age group & & & 6.219 & 0.045 \\
Age group(45-64) & -0.799 & 0.755 & 1.121 & 0.290 \\
Age group(65-105) & -1.472 & 0.685 & 4.624 & 0.032 \\
Score - Wood and paint outside & -0.470 & 0.139 & 11.435 & 0.001 \\
Score - Isolation of the ground floor & -0.192 & 0.097 & 3.933 & 0.047 \\
Score - Foundation & 0.238 & 0.124 & 3.692 & 0.055 \\
Help - In planning the work & -0.686 & 0.411 & 2.781 & 0.095 \\
Help - In finding a good professional / contractor & 0.767 & 0.392 & 3.819 & 0.051 \\
Information - From family / friends & -0.760 & 0.392 & 3.762 & 0.052 \\
Additional driver? - Reduce the transfer tax & & & & \\
if more energy efficient within a year of purchase. & 0.844 & 0.386 & 4.785 & 0.029 \\
Constant & 5.392 & 1.617 & 11.119 & 0.001 \\
\end{tabular}

. For the renovators, the significant stages on help acquisitions are when the renovators have done the work and looked for a reliable professional/ contractor. The significant sources of information are at the maintenance/ installation companies and via the internet.
Table 3. Logistic regression on exterior renovation decision in the last 2 years (renovators)

\begin{tabular}{lrrrrr}
\hline Y & \multicolumn{1}{l}{ B } & \multicolumn{1}{l}{ S.E. } & \multicolumn{1}{c}{ Wald } & \multicolumn{1}{l}{ Sig. } & Exp(B) \\
\hline Age & -0.013 & 0.007 & 3.740 & 0.053 & 0.987 \\
Education & & & 11.968 & 0.018 & \\
education(1) & -1.306 & 0.633 & 4.255 & 0.039 & 0.271 \\
education(2) & -0.569 & 0.335 & 2.886 & 0.089 & 0.566 \\
education(3) & -0.295 & 0.327 & 0.81 & 0.368 & 0.745 \\
education(4) & 0.216 & 0.38 & 0.325 & 0.569 & 1.242 \\
Average net monthly income of households & 0.294 & 0.111 & 7.025 & 0.008 & 1.341 \\
Help - In performing the work (yourself) & 0.615 & 0.225 & 7.437 & 0.006 & 1.849 \\
Help - In finding a good professional/ contractor & 0.396 & 0.193 & 4.220 & 0.040 & 1.486 \\
Information - via an internet page & -0.497 & 0.19 & 6.853 & 0.009 & 0.608 \\
Information - at a maintenance/ installation company & 0.442 & 0.178 & 6.187 & 0.013 & 1.556 \\
Score - Roof construction \& roof covering & -0.128 & 0.069 & 3.403 & 0.065 & 0.88 \\
Score - Glass insulation & -0.217 & 0.069 & 9.917 & 0.002 & 0.805 \\
Score - Wood and paint outside & 0.32 & 0.063 & 25.471 & 0.000 & 1.378 \\
Score - Foundation & 0.154 & 0.066 & 5.51 & 0.019 & 1.167 \\
Hot water - Heating system - Block heating & 0.271 & 0.127 & 4.587 & 0.032 & 1.312 \\
Constant & -0.431 & 0.858 & 0.253 & 0.615 & 0.65 \\
\hline
\end{tabular}

For the potential renovators, the significant stages in help acquisition of potential renovators are whether they are planning to do the work and finding a reliable professional/ contractor. The respondents that have indicated asking information from family and friends are more likely to do a renovation (Table 4).

Table 4. Logistic regression on exterior renovation decision in the next 2 years (potential renovators)

\begin{tabular}{lrrrrr}
\hline & \multicolumn{1}{c}{ B } & \multicolumn{1}{c}{ S.E. } & \multicolumn{1}{c}{ Wald } & \multicolumn{1}{l}{ Sig. } & \multicolumn{1}{l}{ Exp(B) } \\
\hline Age group & & & 6.219 & 0.045 & \\
Age group(45-64) & -0.799 & 0.755 & 1.121 & 0.290 & 0.450 \\
Age group(65-105) & -1.472 & 0.685 & 4.624 & 0.032 & 0.229 \\
Score - Wood and paint outside & -0.470 & 0.139 & 11.435 & 0.001 & 0.625 \\
Score - Isolation of the ground floor & -0.192 & 0.097 & 3.933 & 0.047 & 0.825 \\
Score - Foundation & 0.238 & 0.124 & 3.692 & 0.055 & 1.268 \\
Help - In planning the work & -0.686 & 0.411 & 2.781 & 0.095 & 0.504 \\
Help - In finding a good professional / contractor & 0.767 & 0.392 & 3.819 & 0.051 & 2.153 \\
Information - From family / friends & -0.760 & 0.392 & 3.762 & 0.052 & 0.468 \\
Additional driver? - Reduce the transfer tax & & & & & \\
if more energy efficient within a year of purchase. & 0.844 & 0.386 & 4.785 & 0.029 & 2.326 \\
Constant & 5.392 & 1.617 & 11.119 & 0.001 & 219.615 \\
\hline
\end{tabular}

\subsection{Critical stages and sources of information in the interior type of renovation}

For the renovators, the significance stage in help acquisition is on determining the costs of renovation/ improvement. The respondents that indicate a construction store/ Do-It-Yourself (DIY) companies, and the internet as a reliable source of information are more likely to renovate (Table 5).

Table 5. Logistic regression on the interior renovation in the last 2 years (renovators)

\begin{tabular}{lccccc}
\hline Y & B & S.E. & Wald & Sig. & Exp(B) \\
\hline Age & -0.013 & 0.007 & 3.919 & 0.048 & 0.987 \\
Number of people & & & 10.781 & 0.029 & \\
number of people(1) & 0.306 & 0.203 & 2.281 & 0.131 & 1.358 \\
number of people(2) & 0.649 & 0.312 & 4.331 & 0.037 & 1.913 \\
number of people(3) & 0.954 & 0.335 & 8.130 & 0.004 & 2.596 \\
number of people(4) & 0.746 & 0.486 & 2.357 & 0.125 & 2.108 \\
Help - In determining the costs & -0.590 & 0.180 & 10.787 & 0.001 & 0.555 \\
Information - Via an internet page & 0.784 & 0.205 & 14.599 & 0.000 & 2.190 \\
Information - With family / friends & 0.642 & 0.191 & 11.350 & 0.001 & 1.901 \\
Information - At a construction store / DIY & 1.138 & 0.342 & 11.047 & 0.001 & 3.119 \\
Information - At a maintenance/ installation company y y & 0.594 & 0.183 & 10.498 & 0.001 & 1.810 \\
Score - Toilet and bathroom & 0.106 & 0.062 & 2.949 & 0.086 & 1.112 \\
Constant & -0.117 & 0.600 & 0.038 & 0.845 & 0.889 \\
\hline
\end{tabular}

For the potential renovator, the significant stages in help acquisition are in determining the best way to perform the 
renovation, making the renovation more energy efficient, and finding a reliable professional/ contractor. The significant sources of information are via the internet, from family/ friends, and by a construction store/ DIY company (Table 6).

Table 6. Logistic regression on the planned interior renovation decision in the next 2 years (potential renovators)

\begin{tabular}{lrrrrr}
\hline Y & \multicolumn{1}{c}{ B } & \multicolumn{1}{l}{ S.E. } & \multicolumn{1}{l}{ Wald } & \multicolumn{1}{l}{ Sig. } & \multicolumn{1}{c}{ Exp(B) } \\
\hline Typew(1) & 1.107 & 0.332 & 11.139 & 0.001 & 3.025 \\
Education & & & 7.949 & 0.093 & \\
education(1) & -2.125 & 1.135 & 3.501 & 0.061 & 0.119 \\
education(2) & -0.029 & 0.614 & 0.002 & 0.962 & 0.971 \\
education(3) & -0.342 & 0.557 & 0.377 & 0.539 & 0.710 \\
education(4) & -0.915 & 0.583 & 2.464 & 0.116 & 0.400 \\
Bouwjaar & & & 6.482 & 0.090 & \\
bouwjaar(45-70) & 0.921 & 0.499 & 3.407 & 0.065 & 2.511 \\
bouwjaar(71-90) & -0.074 & 0.410 & 0.032 & 0.858 & 0.929 \\
bouwjaar(>91) & -0.276 & 0.452 & 0.372 & 0.542 & 0.759 \\
Hot water - Heating system - Ordinary combi boiler & -0.688 & 0.349 & 3.897 & 0.048 & 0.503 \\
Help - In determining how they can best & & & & & \\
carry out the renovation / improvement & 0.612 & 0.318 & 3.716 & 0.054 & 1.845 \\
Help - In determining how they can make & & & & & \\
the house more energy-efficient & -1.280 & 0.334 & 14.668 & 0.000 & 0.278 \\
Help - When finding a good professional / contractor & -1.080 & 0.331 & 10.670 & 0.001 & 0.340 \\
- Via an internet page & 0.572 & 0.335 & 2.915 & 0.088 & 1.772 \\
Information - From family / friends & 0.889 & 0.322 & 7.616 & 0.006 & 2.432 \\
Information - At a construction store / do it yourself shop & 1.604 & 0.534 & 9.022 & 0.003 & 4.971 \\
Score - Interior - Paint, wallpaper and tile work & -0.443 & 0.160 & 7.643 & 0.006 & 0.642 \\
Score - Interior - Heating & -0.332 & 0.149 & 4.963 & 0.026 & 0.718 \\
Score - Interior - Electricity & 0.284 & 0.150 & 3.565 & 0.059 & 1.328 \\
Constant & 4.668 & 1.475 & 10.009 & 0.002 & 106.456 \\
\hline
\end{tabular}

\subsection{Critical stages and sources of information in the insulation and installation type of renovation}

For the renovator, the significant stages in help acquisition are in making the house more energy-efficient, planning the work, and finding funding/ financing options. The respondents that indicate a construction store / Do-It-Yourself Company and a maintenance/ installation company a reliable source of information is more likely to renovate (Table 7).

Table 7. Logistic regression on insulation - installation renovation decision in the last 2 years

\begin{tabular}{lrrrrr}
\hline Y & \multicolumn{1}{c}{ B } & S.E. & Wald & Sig. & Exp(B) \\
\hline Help - In determining how they can make the & 1.48 & 0.20 & 55.27 & 0.00 & 4.41 \\
house more energy-efficient & & & & & \\
Help - In planning the work & -0.31 & 0.17 & 3.50 & 0.06 & 0.73 \\
Help - In finding funding - financing options & 0.57 & 0.31 & 3.38 & 0.07 & 1.77 \\
Information - at a construction store / DIY & -0.37 & 0.21 & 3.18 & 0.07 & 0.69 \\
Information - at a maintenance or installation company & 0.40 & 0.16 & 6.30 & 0.01 & 1.48 \\
Average net monthly income of households & -0.25 & 0.09 & 7.07 & 0.01 & 0.78 \\
Hot water - Heating system - HR - Combi Boiler & 0.37 & 0.08 & 19.83 & 0.00 & 1.45 \\
Constant & 0.19 & 0.40 & 0.22 & 0.64 & 1.21
\end{tabular}

For the potential renovators, the significant stages in help acquisitions are in making the house more energy efficient, the best way to carrying out the renovation/ improvement, and in finding funding/ financing options. The identified sources of information are via the internet, maintenance/ installation companies and family and friends (Table 8).
Table 8. Logistic regression on the planned insulationinstallation renovation decision in the next 2 years

\begin{tabular}{llllll}
\hline Y & B & S.E. & Wald & Sig. & Exp(B) \\
\hline $\begin{array}{l}\text { Average net monthly income of } \\
\text { households }\end{array}$ & -0.282 & 0.156 & 3.255 & 0.071 & 0.755 \\
$\begin{array}{l}\text { Number of people } \\
\text { number of people(1) }\end{array}$ & & & & & \\
number of people(2) & 0.609 & 0.298 & 4.705 & 0.046 & \\
$\quad$ number of people(3) & 0.750 & 0.395 & 3.609 & 0.041 & 1.838 \\
$\begin{array}{l}\text { number of people(4) } \\
\text { Help - In determining how they can make }\end{array}$ & 0.950 & 0.405 & 5.510 & 0.019 & 2.117 \\
the house more energy-efficient & 1.430 & 0.562 & 6.468 & 0.011 & 4.178 \\
$\begin{array}{l}\text { Help - In determining how they can best } \\
\text { carry out the renovation/ improvement }\end{array}$ & 0.862 & 0.257 & 11.258 & 0.001 & 2.369 \\
$\begin{array}{l}\text { Help - In finding funding or financing options } \\
\text { Score - Ease of use and comfort of }\end{array}$ & -0.735 & 0.229 & 10.292 & 0.001 & 0.479 \\
the house- Heat insulation of the house & -0.174 & 0.260 & 3.857 & 0.050 & 1.667 \\
Constant & 1.769 & 0.741 & 5.695 & 0.017 & 5.867 \\
\hline
\end{tabular}

\section{Conclusion}

This study contributes to evaluating the transaction cost barriers in a renovation process from the householders' perspectives. An empirical analysis of Dutch homeowners has been conducted based on the survey among 3,776 households. Based on the theory, the asset specificity, uncertainty, and frequency determine the TC. Transaction costs slow down or sometimes prevent the renovation. There are different stages in the renovation which have different TCs. In the beginning, the asset specificity is essential, and in later stages, the uncertainties in the renovation process are critical, such as asymmetric information between the homeowners and contractors. The TC decrease when the homeowners experience the renovation. Based on the regression analysis, the significance of TC of different types of renovation is examined for the homeowners. The main identified conclusions are as follow:

a. For the renovators, the main identified stages in getting help are in carrying out the renovation, determining the costs, and looking for the reliable professional/ contractor. The primary identified sources of information are at the maintenance/ installation companies, family/ friends, and via the internet.

b. For the potential renovators, the main identified help stages are in determining the costs, looking for a reliable professional and carrying out the renovation/ improvement. The primary identified sources of information are via the internet, by maintenance/ installation companies, and family/ friends.

c. The main difference between different types of renovation is for insulation/ installation. The main significant stage in getting help for insulation/installation is to find out how to make the house more energy efficient. For the potential renovators, the similar results have been achieved; the only difference was on the order of the influencing factors.

\section{References}

1. Artola, I., Rademaekers, K., Williams, R. \& 
Yearwood, J. Boosting Building Renovation: What potential and value for Europe? (2016). doi: $10.2861 / 331360$

2. Government of the Netherlands. Dutch Goals within the EU for Climate Change. Government of the Netherlands (2016). Available at: https://www.government.nl/topics/climatechange/eu-policy. (Accessed: 6th February 2018)

3. Ministry of the Interior and Kingdom. Investing in the Dutch housing market. (2014).

4. Government of the Netherlands. Measures to reduce greenhouse gas emissions,. (2017). Available at: https:/www.government.nl/topics/climatechange/national-measures. (Accessed: 23rd October 2017)

5. Aune, M. Energy comes home. Energy Policy 35, 5457-5465 (2007).

6. Mlecnik, E. \& Straub, A. Experiences of Homeowners Regarding Nearly Zero-Energy Renovations and Consequences for Business Models. Plea 2015 Bol. Archit. (R)evolution (2015).

7. Wilson, C., Crane, L. \& Chryssochoidis, G. Why do homeowners renovate energy efficiently? Contrasting perspectives and implications for policy. Energy Res. Soc. Sci. 7, 12-22 (2015).

8. Schilder, F., van Middelkoop, M. \& van den Wijngaart, R. Energiebesparing in de woningvoorraad: financiële consequenties voor corporaties, huurders, eigenaren-bewoners en Rijksoverheid. 50 (2016).

9. Fan, K., Qian, Q. K. \& W Chan, E. H. Transaction Costs (TCs) in Building Regulations and Control for Green Buildings. 818-828 (2016).

10. Mundaca, L., Mansoz, M., Neij, L. \& Timilsina, G. Transaction costs analysis of low carbon technologies. Clim. policy 13, 1-24 (2013).

11. Wilson, C., Pettifor, H. \& Chryssochoidis, G. Quantitative modelling of why and how homeowners decide to renovate energy efficiently. Appl. Energy 212, 1333-1344 (2018).

12. Coase, R. H. The problem of social cost. J. Law Econ. 3, 351-376 (1960).

13. Ostertag, K. Transaction costs of raising energy efficiency. Eng. Anal. Conserv. Energy 18 (1999).

14. Fan, K., Qian, Q. \& Chan, E. Transaction costs (TCs) in building regulations and control for green buildings : case study of Hong Kong. (2016).

15. Williamson, O. E. The Economics of Organization: The Transaction Cost Approach. American Journal of Sociology 87, 548-577 (1981).

16. Williamson, O. Transaction cost economics: the governance of contractual relations. Economic Organization 101-130 (1979). doi:10.1046/j.1365-2702.2003.00683.x

17. Coase, R. H. The Nature of the Firm. Economica 4, 386-405 (1937).

18. Matthews, R. C. O. The Economics of Institutions and the Sources of Growth. Econ. J. 96, 903 (1986).

19. Furubotn, E. G. \& Richter, R. The New Institutional Economics of Markets: An Introduction. New Institutional Econ. Mark. 129 (2010). doi:10.1007/s12273-011-0024-9

20. Björkqvist, O. \& Wene, C. A study of transaction costs for energy investments in the residential sector. in Proceedings of the eceee 1993 Summer Study conference (The European Council for an Energy Efficient Economy Stockholm, 1993).

21. Haurin, D. R. \& Gill, H. L. The impact of transaction costs and the expected length of stay on homeownership. J. Urban Econ. 51, 563-584 (2002).

22. Qian, Q. K., Lehmann, S., Ghani, A., Khalid, B. \& Chan, E. H. W. Transaction Costs (Tcs) Framework to Understand the Concerns of Building Energy Efficiency (BEE) Investment in Hong Kong. Int. J. Waste Resour. 4, 1-7 (2014).

23. Qian, Q. K., Chan, E. H. W., Visscher, H. \& Lehmann, S. Modeling the green building (GB) investment decisions of developers and endusers with transaction costs (TCs) considerations. J. Clean. Prod. 109, 315-325 (2015).

24. Pettifor, H., Wilson, C. \& Chryssochoidis, G. The appeal of the green deal: Empirical evidence for the influence of energy efficiency policy on renovating homeowners. Energy Policy 79, 161176 (2015).

25. Itard, L. \& Meijer, F. Towards a sustainable Northern European Figures, facts and future. (2008).

26. Brown, M. A. Market failures and barriers as a basis for clean energy policies. Energy Policy 29, 1197-1207 (2001).

27. Stieß, I. \& Dunkelberg, E. Objectives, barriers and occasions for energy efficient refurbishment by private homeowners. in Journal of Cleaner Production 48, 250-259 (2013).

28. Mundaca, L. Transaction costs of energy efficiency policy instruments. in (International Institute for Industrial Environmental Economics at Lund University, 2007).

29. Baginski, J. P. \& Weber, C. A Consumer Decision-Making Process? Unfolding Energy Efficiency Decisions of German OwnerOccupiers. HEMF Work. Pap. 08, (2017).

30. Murphy, L. C. Policy Instruments to Improve Energy Performance of Existing Owner 
Occupied Dwellings Understanding and Insight Lorraine. (Delft University of Technology, 2016).

31. Wilson, C. \& Dowlatabadi, H. Models of Decision Making and Residential Energy Use. Annu. Rev. Environ. Resour. 32, 169-203 (2007).

32. Midi, H., Sarkar, S. K. \& Rana, S. Collinearity diagnostics of binary logistic regression model. J. Interdiscip. Math. 13, 253-267 (2010).

33. Brant, R. Assessing Proportionality in the Proportional Odds Model for Ordinal Logistic Regression. Biometrics 46, 1171 (1990).

34. Gigerenzer, G. \& Selten, R. Bounded rationality: The adaptive toolbox. (2001). 